\title{
Characterization of Biological Diversity Through Analysis of Discrete Cranial Traits
}

\author{
Tsunehiko Hanihara, ${ }^{1 *}$ Hajime Ishida, ${ }^{2}$ and Yukio Dodo ${ }^{3}$ \\ ${ }^{1}$ Department of Anatomy and Biological Anthropology, Saga Medical School, Saga 849-8501, Japan \\ ${ }^{2}$ Department of Anatomy, School of Medicine, University of the Ryukyus, Nishihara, Okinawa 203-0215, Japan \\ ${ }^{3}$ Department of Anatomy and Anthropology, Graduate School of Medicine, Tohoku University, Aoba-ku, \\ Sendai 980-8575, Japan
}

\begin{abstract}
KEY WORDS nonmetric cranial traits; geographical variation; interpopulation relationships; modern human origins
\end{abstract}

\begin{abstract}
$A B S T R A C T$ In the present study, the frequency distributions of 20 discrete cranial traits in 70 major human populations from around the world were analyzed. The principal-coordinate and neighbor-joining analyses of Smith's mean measure of divergence (MMD), based on trait frequencies, indicate that 1 ) the clustering pattern is similar to those based on classic genetic markers, DNA polymorphisms, and craniometrics; 2) significant interregional separation and intraregional diversity are present in Subsaharan Africans; 3) clinal relationships exist among regional groups; 4) intraregional discontinuity exists in some populations inhabiting peripheral or isolated
\end{abstract}

For many years, both the single-origin and multiregional hypotheses were used to explain modern human variation (Cann et al., 1987; Cavalli-Sforza et al., 1988; Stringer and Andrews, 1988; Howells, 1989; Wolpoff, 1989). Lahr (1996) wrote that if genetic, chronological, morphological, and archaeological evidence are taken into consideration, a single common origin for Homo sapiens in Africa explains regional differences in modern human populations. Others (Thorne and Wolpoff, 1981; Wolpoff, 1989, 1992; Wolpoff et al., 1984) have consistently maintained that the multiregional hypothesis explains morphological (and genetic) variation in fossil and modern humans. However, Relethford (1994, 1999) and Relethford and Harpending (1994, 1995) demonstrated that both African replacement and multiregional models explain patterns of the genetic and morphological variation if a larger long-term African population size and gene flow are allowed. More recently, Templeton (2002) demonstrated the inadequacies of both the out-of-Africa replacement model and the simple trellis model of Wolpoff $(1989,1992)$, based on the genetic data. Subsaharan Africans have been found to be genetically though not morphologically distant from other populations (Cann et al., 1987; Cavalli-Sforza et al., 1988; Nei and Roychoudhury, 1993). Several studies of dental and cranial morphological variation have shown that Subsaharan Africans and Australasians are distinct areas. For example, the Ainu are the most distinct outliers of the East Asian populations. These patterns suggest that founder effects, genetic drift, isolation, and population structure are the primary causes of regional variation in discrete cranial traits. Our results are compatible with a single origin for modern humans as well as the multiregional model, similar to the results of Relethford and Harpending ([1994] Am. J. Phys. Anthropol. 95:249$270)$. The results presented here provide additional measures of the morphological variation and diversification of modern human populations. Am J Phys Anthropol 121: 241-251, 2003. ๑ 2003 Wiley-Liss, Inc.

(Howells, 1973a, 1989, 1995; Turner, 1992; Lahr, 1995; Relethford and Harpending, 1995; Scott and Turner, 1997; Powell and Neves, 1999). Morphological differentiation in response to environmental factors is often suggested for these differences (Beals, 1972; Guglielmino-Matessi et al., 1979; Scott and Turner, 1997). Although the relationship between craniofacial form and environmental factors was examined by Beals (1972) and Guglielmino-Matessi et al. (1979), adaptive responses to different selective forces over a period of time cannot be directly tested. How can the morphological diversity of modern humans be explained in the framework of modern hu-

\footnotetext{
Grant sponsor: Ministry of Education, Science and Culture of Japan; Grant numbers: Grants-in-Aid for Scientific Research 10115204 09839003, 1440521, 14540659; Grant sponsor: Japan Fellowship for Research in the Former Soviet Union and United Kingdom, Japan Society for the Promotion of Science; Grant sponsor: Smithsonian Institution Fellowship Program, Smithsonian Opportunities for Research and Study.
}

\footnotetext{
*Correspondence to: Tsunehiko Hanihara, Department of Anatomy and Biological Anthropology, Saga Medical School, 5-1-1 Nabeshima, Saga 849-8501, Japan. E-mail: hanihara@post.saga-med.ac.jp
}

Received 12 December 2000; accepted 21 November 2002.

DOI 10.1002/ajpa.10233 
TABLE 1. Range of $N$ in samples (since each of traits observed has a different $N$ ) and numbers of mandibles in parentheses for males and females, and brief information ${ }^{1}$

\begin{tabular}{cccc}
\hline & \multicolumn{2}{c}{$\mathrm{N}$} \\
\cline { 2 - 3 } Sample name & Males & Females & Brief information and location of collections \\
\hline
\end{tabular}

\author{
East Asians \\ 1. Japanese \\ 2. Hokkaido Ainu \\ 3. Sakhalin in Ainu \\ 4. North Chinese \\ Southeast Asians \\ 5. Myanmar \\ 6. Mainland SE Asians \\ 7. Javanese \\ 8. Philippines \\ 9. Borneans \\ 10. Lesser Sunda
}

11. Andamanese/Nicobarese

Northeast Asians

12. Mongolians

13. Buryats

14. Amur Basin

15. Neolithic Baikalians

16. Yakuts

Arctic

17. Ekvens

18. Chukchis

19. Aleuts

20. Asian Eskimos

21. Greenland Eskimos

New World

22. Northwest Coast

23. Northwest America

24. Northeast America

25. Central America

26. Peruvians

27. Fuegians/Patagonians

Micronesians

28. Mariana

Polynesians

29. Hawaii

30. Easter

31. Marquesas

32. Maori

33. Moriori

Melanesians

34. Papua New Guinea

35. Torres Strait

36. North Melanesians

37. South Melanesians

Australians

38. East Australians

39. South/West Australians

Tibet/Nepal/Northeast

India

40. Tibetans/Nepalese

41. Assam/Sikkim

South Asians

42. Northeast India

43. South India

44. Northwest India

Central Asians

45. Tagars

46. Kazakhs

\begin{tabular}{|c|c|}
\hline $\begin{array}{c}98-108(94) \\
122-151(113) \\
62-65(54) \\
132-139(75)\end{array}$ & $\begin{array}{l}62-64(59) \\
84-108(76) \\
28-29(32) \\
26-27(14)\end{array}$ \\
\hline $\begin{array}{c}132-135(48) \\
125-141(105) \\
94-97(83) \\
135-144(49) \\
78-109(74) \\
52-54(39)\end{array}$ & $\begin{array}{l}47-49(3) \\
41-43(30) \\
32-26(32) \\
62-66(31) \\
37-40(21) \\
11-12(6)\end{array}$ \\
\hline $65-71(43)$ & $40-43(30)$ \\
\hline $\begin{array}{c}116-121(69) \\
76-81(65) \\
85-92(57)\end{array}$ & $\begin{array}{l}53-59(38) \\
64-69(58) \\
67-74(48)\end{array}$ \\
\hline $\begin{array}{l}40-59(45) \\
43-45(38)\end{array}$ & $\begin{array}{l}14-22(19) \\
19-20(18)\end{array}$ \\
\hline $\begin{array}{l}45-55(48) \\
43-48(17)\end{array}$ & $\begin{array}{l}49-56(44) \\
22-26(10)\end{array}$ \\
\hline $\begin{array}{l}63-67(48) \\
66-73(48) \\
82-85(47)\end{array}$ & $\begin{array}{l}30-43(17) \\
53-59(16) \\
70-76(25)\end{array}$ \\
\hline $\begin{array}{l}53-59(15) \\
48-61(40)\end{array}$ & $\begin{array}{l}29-35(12) \\
19-24(16)\end{array}$ \\
\hline $42-50(20)$ & $21-29(8)$ \\
\hline $45-58(21)$ & $24-30(12)$ \\
\hline $\begin{array}{c}115-123(60) \\
39-44(24)\end{array}$ & $\begin{array}{l}55-60(33) \\
20-23(7)\end{array}$ \\
\hline $91-120(82)$ & $70-93(75)$ \\
\hline $\begin{array}{c}82(58) \\
63-79(41) \\
55-61(24) \\
109-140(58) \\
66-78(24)\end{array}$ & $\begin{array}{l}63-64(42) \\
59-71(31) \\
39-42(9) \\
37-49(23) \\
18-20(6)\end{array}$ \\
\hline 54-175 (84) & $51-154(83)$ \\
\hline $\begin{array}{l}59-65(37) \\
64-196(119)\end{array}$ & $\begin{array}{l}35-38(37) \\
41-103(72)\end{array}$ \\
\hline 58-137 (67) & $27-57(33)$ \\
\hline $53-88(55)$ & $33-46$ (36) \\
\hline $86-260$ (159) & $34-128$ (77) \\
\hline 91-94 (58) & $23-25(4)$ \\
\hline $40-41(30)$ & 23-24 (19) \\
\hline $\begin{array}{c}90-93(61) \\
123-127(65) \\
125-131(71)\end{array}$ & $\begin{array}{l}23-24(14) \\
45-46(30) \\
32-35(16)\end{array}$ \\
\hline $\begin{array}{l}62-72(44) \\
75-77(75)\end{array}$ & $\begin{array}{l}60-76(50) \\
42-43(42)\end{array}$ \\
\hline
\end{tabular}

Tokyo and Tohoku (Northern Japan) regions (UT, TU)

Recent Ainu people (SMU, UT)

Southern Sakhalin (MAE, MSU, KU, MH)

Mainly from Liaoning Prefecture (UT, KU)

Recent Burmese (NHM, UC)

Thai, Vietnam, Laos, Cambodia, and Malay (NHM, UC, MH)

Greater Sunda islands (NHM, UC, MH, AMNH)

Non-Negrito Filipinos (NHM, UC, MH)

Mainly land Dayaks (NHM, UC, MH)

Timor, Bali, Sumbawa, Flores, and Celebes Islands (NHM, $\mathrm{UC}, \mathrm{MH}, \mathrm{AMNH})$

Andaman Negritos and Nicobar Islands (NHM, UC, MH)

Ulan Bator (Urga) and other regions (MH, NMNH, AMNH) From Northeast Siberia (MAE, MH, NMNH)

Ulchs, Nanaians, Negidals, Nivkhs, and Orochs (MAE, MSU, $\mathrm{MH})$

From around Lake Baikal (MAE, MSU, ISU)

From Northeast Siberia (MAE, MSU, MH)

Iron-Age people from Ekven site, Chukot Peninsula (MSU)

From Arctic region of Northeast Siberia (MAE, MSU, MH, NMNH, AMNH)

Mainly from Unalaska Island (NMNH, AMNH)

From Arctic region of Northeast Siberia (MAE, MSU)

West Coast of Greenland (NHM, UC, MH, AMNH, NMNH)

Northwest Coast of Canada (NHM, UC)

Plateau, Great Basin, California, and Southwest Cultural areas (NHM, UC, MH)

Great Plains, Northeast, and Southeast Cultural areas (NHM, UC)

Mexico, Colombia, Ecuador, Carib, Venezuela, and Guyana (NHM, UC)

Cerro del Oro, Huacho, Pisagua, etc. (NHM)

Terra del Fuego and Patagonia region (NHM, UC, MH)

Guam, Saipan, and Tinian (BM, MH)

Mainly from Oahu Island (NHM, UC)

Easter Islanders (NHM, UC, MH, AM, US, SAM)

Mainly from Uahuka Island (NHM, MH)

New Zealand (NHM, UC, AM, US, SAM)

Chatham Islands (NHM, UC, AM, US)

Purari River delta, Fly River delta, Sepik River Delta, etc. (NHM, AM, US, SAM)

Island of Torres Strait (NHM, UC, MH)

New Ireland, New Britain, Solomon, and Santa Cruz (NHM, UC, AM, US, SAM)

Loyalty, New Caledonia, Vanuatu, and Fiji (NHM, UC, AM, US, SAM)

New South Wales, Queensland, and Victoria (AM, NHM, $\mathrm{UC}, \mathrm{MH}, \mathrm{AMNH}$ )

South Australia and Western Australia (SAM, NHM, UC, $\mathrm{MH}, \mathrm{AMNH})$

Tibetan Soldiers (19th Century), lowland of Nepal (NHM, UC)

Darjeeling, Assam, and Sikkim districts (NHM)

Bengal and Bihar districts (NHM)

Madras, Tamil Natu, Malabar Coast, and Karnataka (NHM)

Punjab and Kashmir districts (NHM)

Iron-Age Tagar culture (MAE, MSU)

From Central Asia, Kazakh (MAE) 
TABLE 1. (Continued)

\begin{tabular}{|c|c|c|c|}
\hline \multirow[b]{2}{*}{ Sample name } & \multicolumn{2}{|c|}{$\mathrm{N}$} & \multirow[b]{2}{*}{ Brief information and location of collections } \\
\hline & Males & Females & \\
\hline \multicolumn{4}{|l|}{ Europeans } \\
\hline 47. Russians & $72-74(74)$ & $45-47(41)$ & Recent Russians (NHM, UC, MAE, MSU) \\
\hline 48. Greece & $46-54(20)$ & $12-16(4)$ & Ancient and recent Greece (NHM) \\
\hline 49. Eastern Europeans & $80-98(52)$ & $18-24(16)$ & $\begin{array}{l}\text { Slav group: Poland, Czecho, Hergegovina, Bulgaria, and } \\
\text { Yugoslavia (NHM) }\end{array}$ \\
\hline 50. Italy & $131-146(82)$ & $42-47(31)$ & Recent Italians (NHM) \\
\hline 51. Finland/Ural & $72-75(35)$ & $5-6(2)$ & $\begin{array}{l}\text { Including a few samples of Ural-language people (NHM, } \\
\text { MH) }\end{array}$ \\
\hline 52. Scandinavia & $57-60(30)$ & $5(3)$ & Norwegians and Swedish (NHM, UC) \\
\hline 53. Germany & $58-61(44)$ & $9-10(7)$ & Recent German (NHM, UC) \\
\hline 54. France & $74-86(23)$ & $18-21(0)$ & Recent French (NHM, UC, MH) \\
\hline \multicolumn{4}{|l|}{ UK series } \\
\hline 55. Ensay & $64-68(58)$ & $29-30(30)$ & Late Medieval to post-Medieval periods, Scotland (NHM) \\
\hline 56. Poundbury & $97-109(106)$ & $46-52(47)$ & Late Roman period, Southwest England (NHM) \\
\hline 57. Spitalfields-1 & $122-135(121)$ & $104-113(106)$ & Mid-Victorian, London (NHM) \\
\hline 58. Spitalfields-2 & $73-74(75)$ & $17-19(35)$ & Pre-17th century, London (UC) \\
\hline \multicolumn{4}{|l|}{ North Africans } \\
\hline 59. Naqada & $82-87(57)$ & 89-93 (39) & Predynastic Egypt, ca. 5,000-4,000 BP (UC) \\
\hline 60. Gizeh & $122-125(91)$ & $46-51(32)$ & 26th-30th Dynasty, Egypt, 664-343 BC (UC) \\
\hline 61. Kerma & $114-132(58)$ & $79-92(51)$ & 12 th-13th Dynasty of Nubia (UC) \\
\hline 62. Nubia & 86-92 (39) & $42-47(9)$ & Early Christian or Christian date Nubia (UC) \\
\hline \multicolumn{4}{|l|}{ Subsaharan Africans } \\
\hline 63. Somalia & $58-64(53)$ & $10-12(5)$ & Erigavo District, Ogaden Somali (US) \\
\hline 64. Nigeria-1 & $74-83(72)$ & $65-76(53)$ & Ibo tribe (NHM, UC) \\
\hline 65. Nigeria-2 & $73-80(17)$ & 46-53 (7) & Ashanti tribe (NHM, UC) \\
\hline 66. Gabon & $82-86(47)$ & $55-57(36)$ & Fernand Vaz River (NHM, NMNH) \\
\hline 67. Tanzania & $69-75(54)$ & $20-25(17)$ & Haya tribe, Musira Island, Lake Victoria (UC, NHM) \\
\hline 68. Kenya & $71-82(31)$ & $55-63(10)$ & Bantu-speaking people from Kenya (UC, NHM) \\
\hline 69. South Africa & $100-109(53)$ & $21-25(8)$ & Zulu and once called Kaffir tribes (UC, NHM, AMNH) \\
\hline 70. Khoisans & $43-36(28)$ & $17-22(13)$ & Bushmans and Hottentots (NHM, UC, AMNH) \\
\hline
\end{tabular}

${ }^{1}$ NHM, Natural History Museum, London, UK; UC, University of Cambridge, Duckworth Laboratory, Cambridge, UK; MH, Museé de l'Homme, Paris, France; MAE, Museum of Anthropology and Ethnography, St. Petersburg, Russia; MSU, Moscow State University, Institute of Anthropology, Moscow, Russia; AM, Australian Museum, Sydney, Australia; US, University of Sydney, Sydney, Australia; SAM, South Australian Museum, Adelaide, Australia; AMNH, American Museum of Natural History, New York; NMNH, National Museum of Natural History, Smithsonian Institution, Washington, DC; BM, Bishop Museum, Honolulu; UT, University of Tokyo, University Museum, Tokyo, Japan; TU, Tohoku University, Department of Anatomy and Anthropology, Sendai, Japan; KU, Kyoto University, Kyoto, Japan; SMU, Sapporo Medical University, Sapporo, Japan.

man evolution? Several pioneering examinations of craniofacial and dental variation may provide an answer.

Howells (1989) found that modern regional craniofacial differences are small relative to the differences between modern populations and Neanderthals. Relethford (1994) and Relethford and Harpending (1994) also found that the amount of morphological variation among major geographic groups is relatively low, and is compatible with those based on the genetic data. Further, Relethford and Harpending (1994) showed that Subsaharan African populations were the most divergent once regional differences in population size were taken into account in computing biological distances between regions. Lahr (1994, 1995, 1996) and Lahr and Wright (1996) concluded that the morphological characters often cited as evidence of the multiregional model are actually due to the differential retention of traits from a single ancestor.

Scott and Turner (1997) summarized dental morphology data from thousands of individuals and hundreds of groups. The numerical scale and worldwide synthesis of global variation rival quantitatively and qualitatively the craniometric data gathered by Howells (1973a, 1989, 1995). Cladistic analyses of dental morphological traits generally support the single-origin hypothesis for anatomically modern humans (Irish, 1997, 1998; Stringer et al., 1997; Tyrrell and Chamberlain, 1998).

Except for a few studies (Berry and Berry, 1967; Hertzog, 1968; Hauser and De Stefano, 1989; Manzi et al., 1996, 2000), large-scale analyses of discrete cranial traits to assess interpopulation relationships have not been performed. In morphological studies, we are faced with a need to explain the evolutionary processes by which the morphological variation likely developed (Relethford and Harpending, 1994; Lahr, 1995, 1996; Lahr and Wright, 1996). Our previous studies (Hanihara et al., 1998a,b; Hanihara and Ishida, 2001a-e) suggest that many discrete cranial traits show distinctive geographical variation, interregional clines, intraregional discontinuity, and changes over time. We concluded that founder effect, genetic drift, and population structure are the underlying causes for the observed regional variation. The purpose of this paper is to analyze and interpret interregional relationships of worldwide human populations, using discrete cranial traits. We address how the analysis of these traits contributes to our understanding of modern human origins. 
TABLE 2. Discrete cranial traits used in this study and references

\begin{tabular}{ll}
\hline \multicolumn{1}{c}{ Traits } & \multicolumn{1}{c}{ References } \\
\hline Supernumerary ossicles & Hanihara and Ishida (2001b) \\
Ossicle at lambda & Dodo (1974) \\
Parietal notch bone & Dodo (1974) \\
Asterionic bone & Ossenberg (1969, 1970) \\
Occipitomastoid bone & Dodo (1974), Ossenberg (1970) \\
Hypostotic traits & Hanihara and Ishida (2001c) \\
Tympanic dehiscence & Dodo (1974) \\
Ovale-spinosum confluence & Dodo (1974) \\
Metopism & Hauser and De Stefano (1989) \\
Biasterionic suture & Dodo (1974), Ossenberg (1969), \\
& Hanihara and Ishida (2001a) \\
Transverse zygomatic & Dodo (1974), Hanihara et al. \\
suture & $(1998$ a) \\
Hyperostotic traits & Hanihara and Ishida (2001d) \\
Medial palatine canal & Dodo (1974), Hauser and De \\
& Stefano (1989) \\
Hypoglossal canal bridging & Dodo (1974) \\
Jugular foramen bridging & Dodo (1986a,b) \\
Mylohyoid bridging & Dodo (1974), Jidoi et al. (2000) \\
Precondylar tubercle & Hanihara and Ishida (2001d) \\
Condylus tertius & Dodo (1974) \\
Auditory exostosis & Dodo (1972), Kennedy (1986), \\
& Standen et al. (1997) \\
Vessel/nerve-related traits & Hanihara and Ishida (2001e) \\
Condylar canal patent & Dodo (1974), Hauser and De \\
Supraorbital foramen & Stefano (1989) \\
Accessory infraorbital & Dodo (1974, 1987) \\
foramen & Berry and Berry (1967) \\
Accessory mental foramen & Murphy (1957), De Villiers \\
& $(1968)$, Gershenson et al. \\
& $(1986)$ \\
\hline & \\
&
\end{tabular}

\section{MATERIALS AND METHODS}

Seventy samples with a relatively large sample size were used in the multivariate statistical analysis. Table 1 provides the sample names, sample sizes, and brief information on each sample. All samples were made up of adult specimens without cranial deformations. The principal criteria used to determine adult status were complete fusion of the sphenooccipital synchondrosis and fully erupted third molars, if available.

Twenty discrete cranial traits (Table 2) were analyzed with respect to sex and side differences, intertrait association, and frequency distributions in a series of 70 late prehistoric, historic, and recent samples, totaling more than 8,000 individuals from around the world. The details of samples and their archaeological, geographical, and ethnological contexts are provided elsewhere (Hanihara and Ishida, $2001 \mathrm{~b}-\mathrm{e})$. The scoring procedures for each trait are further described in Hanihara and Ishida (2001b-e). The scoring of graded traits (transverse zygomatic suture vestige, biasterionic suture vestige, jugular foramen bridging, and mylohyoid bridging) was converted to present or absent, following Dodo (1974). While observations were made for each side in bilateral traits, the individual count method was used; if a trait was present on either or both sides, it was scored as present (Dodo, 1974; Hauser and De Stefano, 1989; Turner et al., 1991). For all groups, Fisher's exact probability test showed that the expres- sion of most traits does not differ significantly between the right and left sides and does not show any side preference in unilateral expression (Hanihara and Ishida, 2001b-e).

Sex differences were found in a few traits, such as presence of asterionic bone, biasterionic suture vestige, and tympanic dehiscence. However, the sexes were pooled in this study because of a roughly consistent male/female ratio (2:1-3:1) in the majority of samples, except for the European samples, which are overwhelmingly male.

Although several statisticians and geneticists (e.g., Balakrishnan and Sanghvi, 1968; Edwards and Cavalli-Sforza, 1972; Konigsberg, 1990) have developed a wide array of techniques for estimating biological distance using genetic or phenotypic trait frequencies in samples, the modified Smith's mean measure of divergence (MMD) (Sjøvold, 1973) was applied for estimating biological divergence between each pair of samples in this study. Although the development and use of different distance statistics have proceeded with some controversy, and some authors have pointed out the advantages of one particular method and the weaknesses of alternative approaches, the usefulness for MMD was recently addressed (Scott and Turner, 1997; Dodo et al., 1998). Since many workers specializing in discrete cranial and dental traits often employ MMD (e.g., Berry and Berry, 1967; Turner, 1987, 1992; Ossenberg, 1986; Dodo et al., 1992, 1998; Irish, 1997, 1998; Scott and Turner, 1997), the results obtained by MMD statistics in this study can be directly compared with such previous works without methodological controversy. According to Cavalli-Sforza et al. (1994), moreover, the distances calculated by different formulae are always highly correlated.

The MMD is not based on population genetic models. As such, it is a model-free, rather than modelbound measure (Howells, 1973b; Relethford and Lees, 1982). The MMD is based on an assumption of trait independence. In our previous studies, the average intertrait correlation in each sample was low, with Phi coefficients ranging from $0.00-0.28$, with a mean correlation of 0.08 . Higher correlations among morphogenetically similar (hyperostotic or hypostotic) traits have been found (Berry and Berry, 1967; Hertzog, 1968; Ossenberg, 1969; Corruccini, 1974; Hauser and De Stefano, 1989). However, the patterns of geographical variation tend to be different from trait to trait, even in the same category, suggesting the more or less independent expression of these traits (Hanihara and Ishida, 2001b-e). Based on these results, we assume that the MMD will not be seriously biased.

Principal coordinate analysis and the neighborjoining method (Saitou and Nei, 1987) were applied to the MMD distance matrix to visualize the intergroup relationships with a minimum loss of information present in the original distances. 


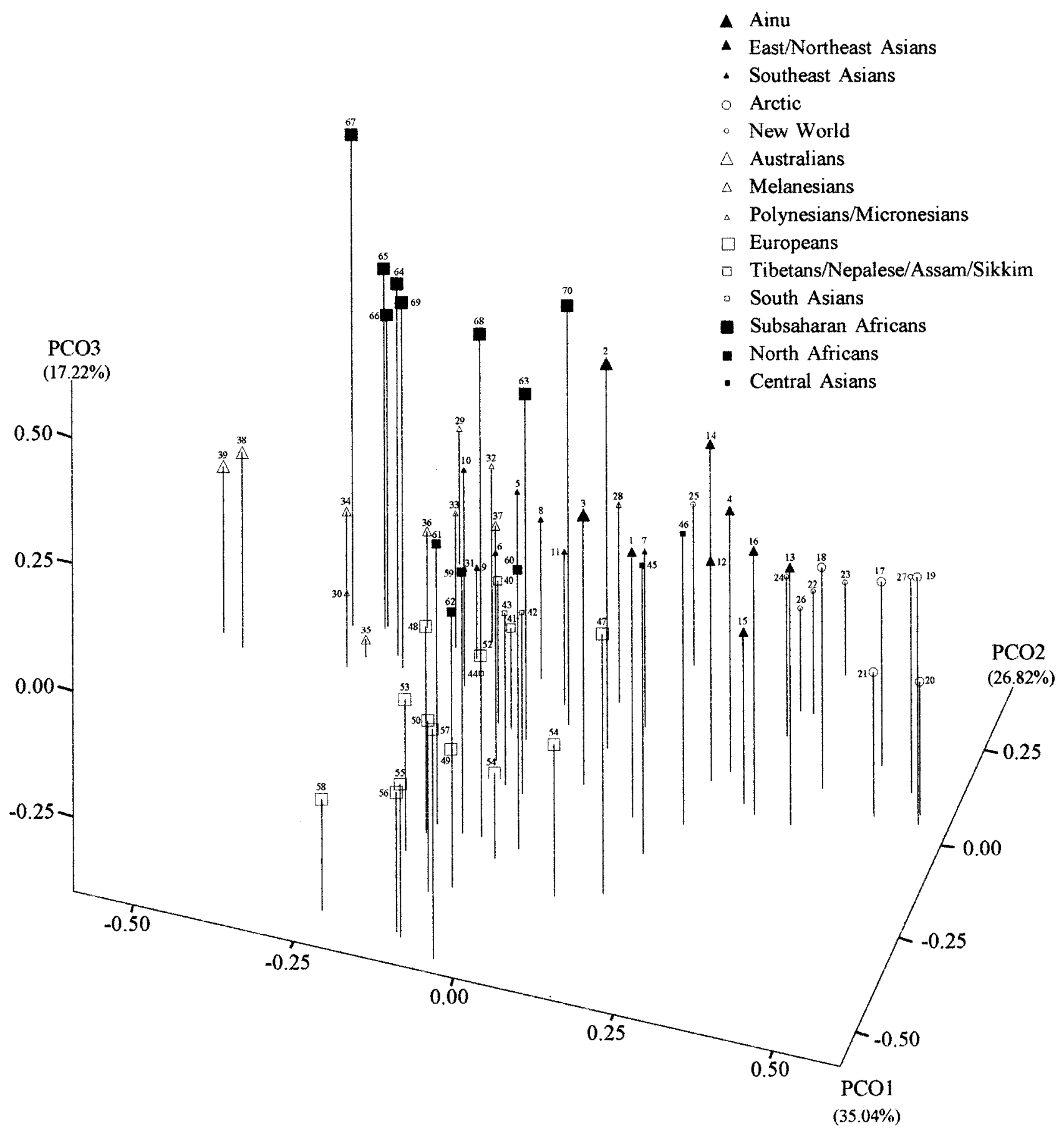

Fig. 1. Three-dimensional display of sample affinities by principal coordinate analysis based on MMD distance matrix. Numbers correspond to sample numbers in Table 1.

\section{RESULTS}

The principal coordinate analysis of the MMD matrix (not shown because of its unwieldy size) was performed first. With a few exceptions (some pairs in Southeast Asian samples), the MMD between each pair of samples was significant at the $5 \%$ level or less. A plot of the 70 samples on the first three principal coordinates is presented in Figure 1. The first three coordinates represent approximately $80 \%$ of the information in the distance matrix. To aid in interpretation, two-dimensional scatter plots were drawn, using the first through fourth principal coordinates, all of which have eigenvalues greater than 1.0 (Fig. 2).

Roughly three major constellations are evident. The Subsaharan African, Southeast Asian, and Oceanian samples form a cluster in one quadrant of Figure 2a. However, the Subsaharan African sam- 


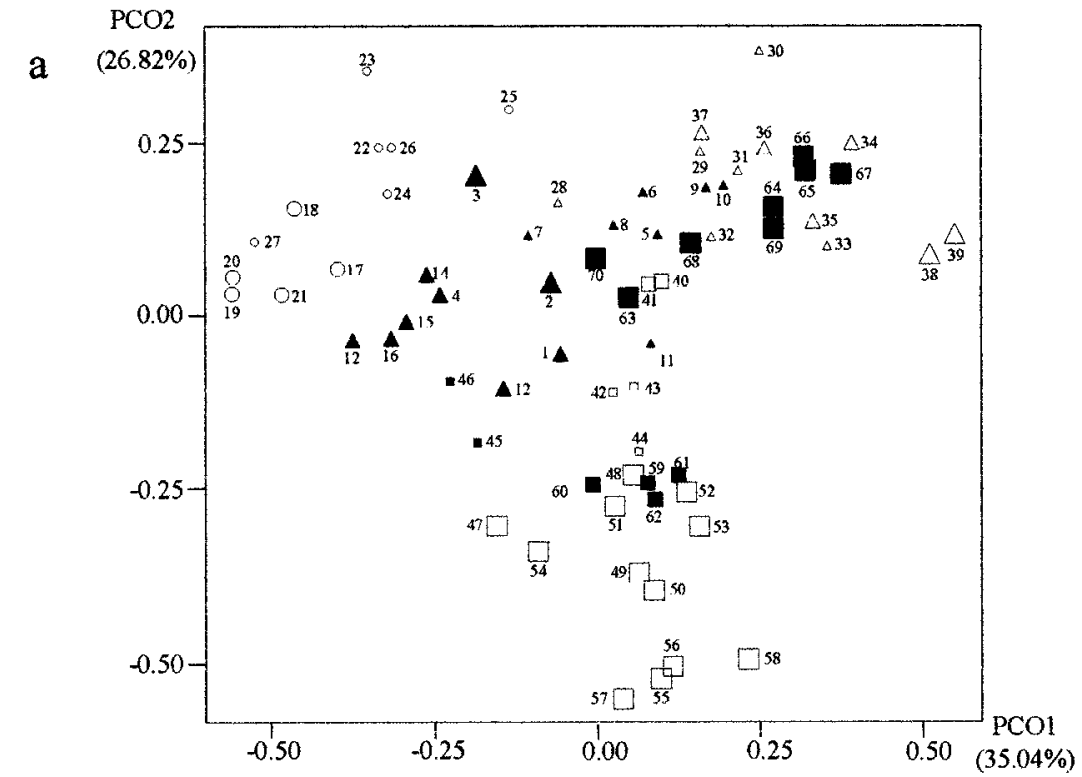

$\Delta$ Ainu

- East/Northeast Asians

- Southeast Asians

- Arctic

- New World

$\triangle$ Australians

$\triangle$ Melanesians

$\triangle$ Polynesians/Micronesians

$\square$ Europeans

$\square$ Tibetans/Nepalese/Assam/Sikkim

- South Asians

- Subsaharan Africans

- North Africans

- Central Asians

$\mathrm{PCO}$

b
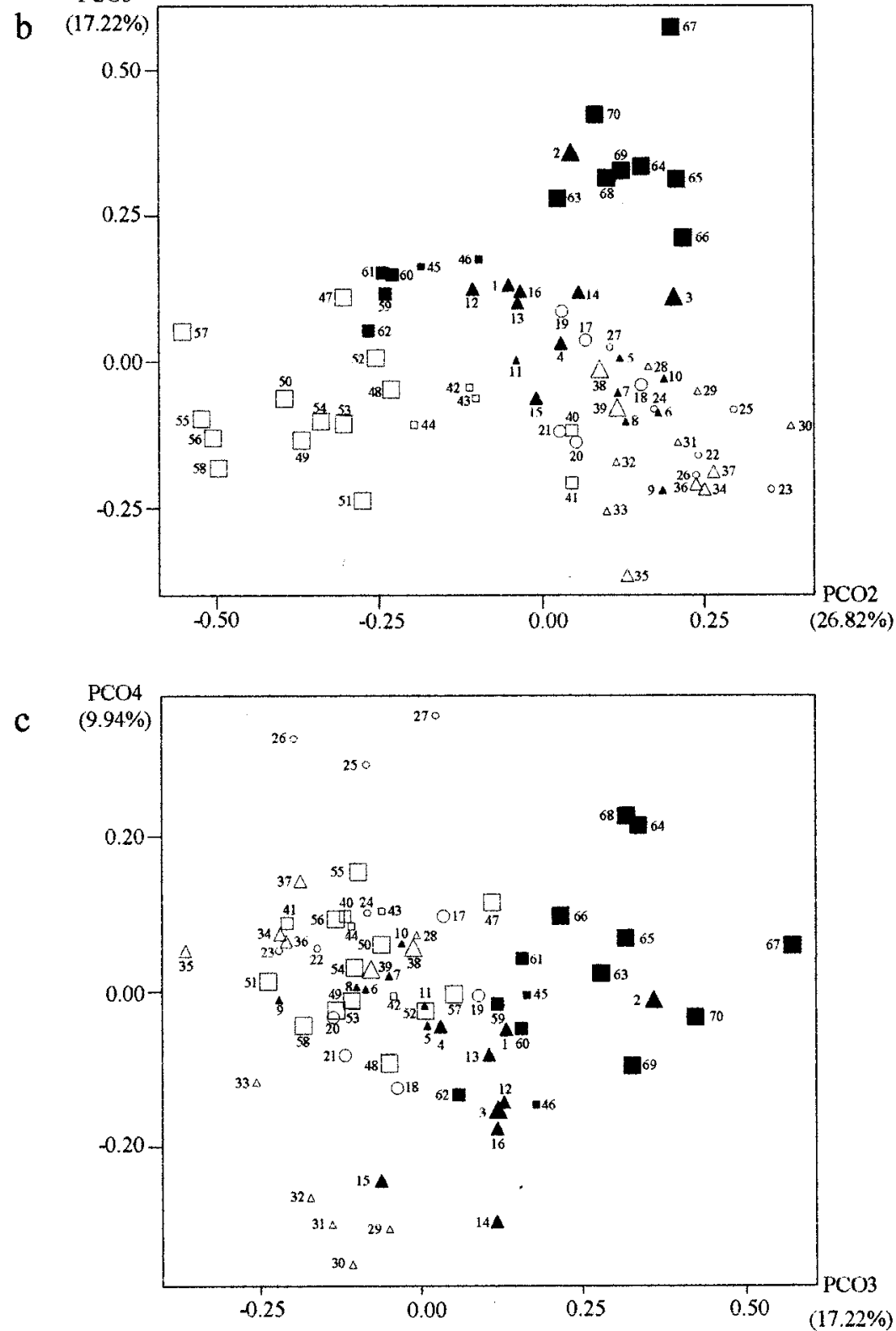

Fig. 2. Two-dimensional scattergrams drawn by using first-second (a), second-third (b), and third-fourth (c) principal coordinates. Numbers correspond to sample numbers in Table 1. 
ples form a distinct grouping, well removed from the Southeast Asian and Oceanian samples on the third and fourth principal coordinates. In Figures 1 and 2, the Subsaharan African samples show significant separation from other regions, as well as diversity among themselves. The East/Northeast Asian and European samples form two additional discernable clusters. The New World and Arctic samples are peripheral subgroups in the large East/Northeast Asian cluster, and the two Ainu samples are outliers to other East Asians. The Central Asian samples are located between the Eastern Asian and European clusters. In the bottom half of Figure 2a, the South Asian samples are nearest to the center of all groups, the North African samples are a bit further removed, and the European samples are more separated, having the lowest scores on principal axis 2 .

Applying the neighbor-joining method to the MMD distances results in the dendrogram illustrated in Figure 3. The initial split, suggesting the greatest dissimilarity, is between Subsaharan Africans and the rest of the world. The Europeans, North Africans, and South Asians are then separated from the remaining groups. Oceania and the Southeast Asian groups form a separate branch that is separated from a large grouping of Central and East/Northeast Asian, Arctic, and New World series clusters. The Arctic cluster, which includes groups from northeasternmost Siberia, is deep in a branch containing all New World groups. The Ainu samples are more similar to mainland groups from the Amur River basin and Lake Baikal than to the Japanese.

\section{DISCUSSION}

In the present study, we analyzed discrete cranial data from several thousand individuals and many populations from around the world. The results of our multivariate analyses provide support for the geographical distinctiveness of the populations. In fact, the patterns of divergence shown in Figures 1-3 are roughly consistent with the genetic and craniometric trees (Howells, 1989; Cavalli-Sforza et al., 1994). The clustering pattern presented here suggests, at the same time, that the variation in discrete cranial traits is, at least in part, due to intergroup genetic differences rather than mainly environmental factors. We acknowledge, however, that discrete cranial traits have an underlying threshold mode of inheritance, and thus the use of frequencies in MMD may not directly reflect underlying allele frequencies.

This study revealed the clinal nature of discrete cranial trait variation across regions and the morphological discontinuity in isolated populations such as the Ainu, Andamanese/Nicobarese, and Pacific peoples. These results suggest that limited gene flow and local adaptation allowed such peripheral groups to maintain their distinctiveness. These results are consistent with the interpretation of Lahr (1996) that the diversity of modern human cranial features may be attributed to the differential retention, spe- cialization, loss, and intensification of certain morphological traits from ancestral patterns. If this is true, as seems likely, then we suggest that it is still too soon to accept any particular model of modern human diversity and interpopulation relationships such as those proposed by Omoto (1995), Brace et al. (2001), and others. Genetic and craniometric data provide only part of the evidence needed to answer questions of modern human origins and the evolution of modern human diversity. Additionally, data should illuminate the population histories and affinities of peripheral groups such as the Ainu.

Another notable result is the significant regional differences between Subsaharan Africans and the other regional populations in the world. According to many geneticists (e.g., Cann et al., 1987; Vigilant et al., 1991; Stoneking, 1993) and morphological anthropologists (Stringer and Andrews, 1988), the single-origin hypothesis for the emergence of anatomically modern humans entails that the greatest difference of physical characteristics will be found between Subsaharan Africans and other geographical populations. However, the present findings are also consistent with the multiregional hypothesis (Thorne and Wolpoff, 1981; Wolpoff, 1989, 1992; Wolpoff et al., 1984). Certainly, regional morphological diversity will reflect the combination of several factors, such as adaptation to different environments, different subsistence patterns, random drift, gene flow, and isolation (Howells, 1989; Turner, 1990; Relethford, 1994; Lahr, 1995).

Although the clustering pattern shown in Figure 3 is roughly compatible with those constructed by genetic data (Cavalli-Sforza et al., 1988; Nei and Roychoudhury, 1993; Ruiz-Linares et al., 1995; Omoto and Saitou, 1997) and cladistic trees using dental data (Stringer et al., 1997; Irish, 1998; Tyrrell and Chamberlain, 1998), it is also compatible with a model of regional differences in population size and rates of gene flow. As shown in Relethford and Harpending (1994, 1995), Relethford (1999), and Relethford and Jorde (1999), differences in population size and gene flow can easily mimic a recent Subsaharan African origin. A model with Subsaharan Africa having the largest long-term population size and greater gene flow out of Africa than into Africa replicates the observed patterns of higher within-region variation in Africa and greater separation of Africans from non-African populations (Relethford and Harpending, 1995; Relethford, 1999; Relethford and Jorde, 1999). Such results inform us about patterns of gene flow and population size, and do not necessarily support one model of modern human origins over another.

As described previously, the purpose of the present study was not to test the multiregional vs. single-origin hypotheses. Our main purpose was to stress that discrete cranial traits provide biological distances similar to those found in genetic and other morphological analyses. Regardless of which modern-human-origins model is correct (if either is ab- 


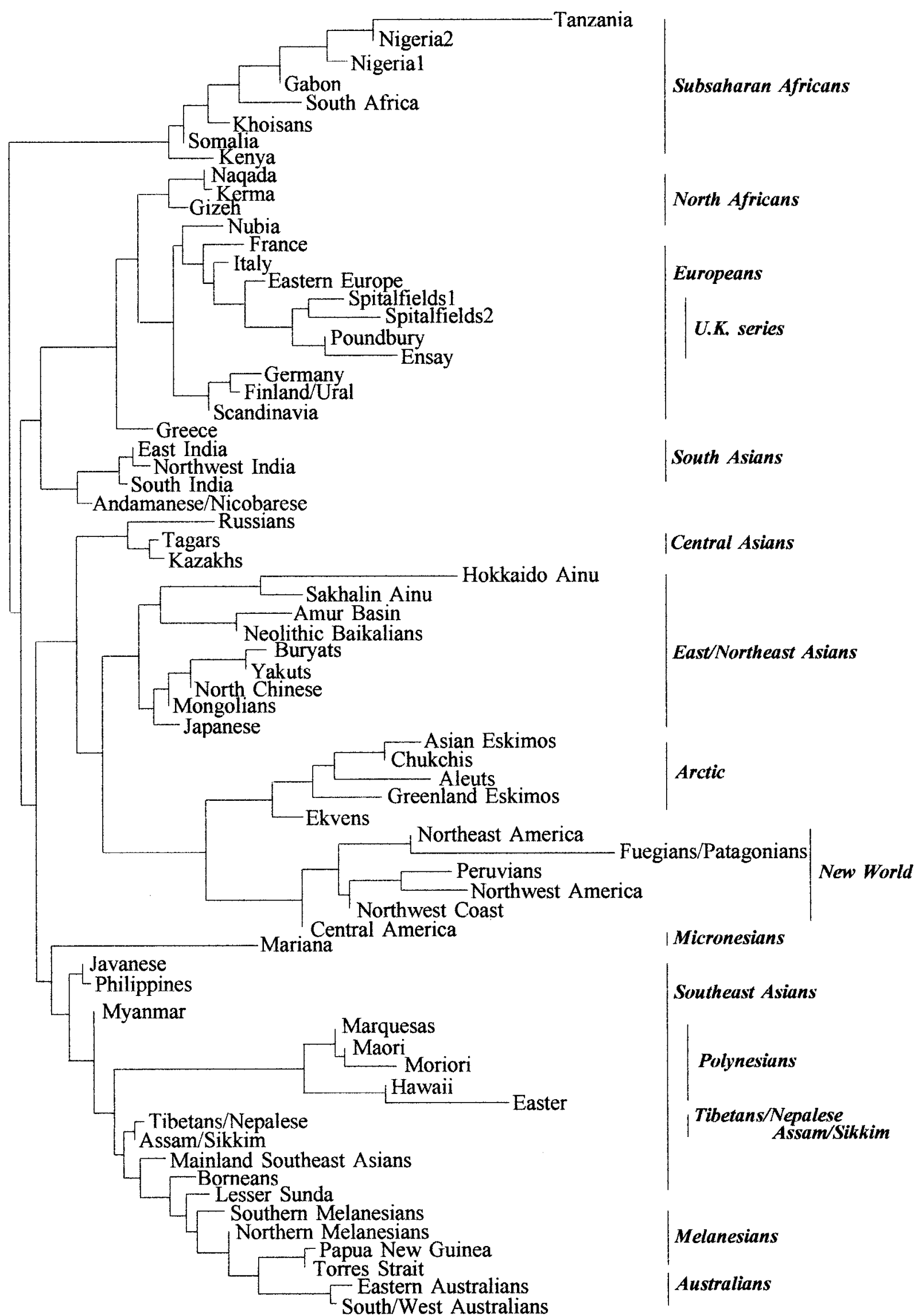

Fig. 3. Result of clustering by neighbor-joining method applied to MMD distance matrix. 
solutely), or whether such analyses can decisively test the models, it is clear that different types of data reflect similar patterns, whether or not we can know for certain the causes of such patterns.

\section{ACKNOWLEDGMENTS}

We express our sincere gratitude to Stephen Ousley of the National Museum of Natural History, Smithsonian Institution (Washington, DC), for his critical advice and for editing the English-language text. For their kind permission to study the materials under their care, we express our sincere thanks to T. Molleson, R. Kruszynski, L.T. Humphrey, and C. Stringer of the Natural History Museum (London, UK); R. Foley, M.M. Lahr, and M. Bellatti of the Department of Biological Anthropology, University of Cambridge (Cambridge, UK); A. Langaney and M.A. Pereira da Silva of the Laboratoire d'Anthropologie Biologique, Musée de l'Homme (Paris, France); D. Hunt, S. Ousley, D. Owsley, R. Potts, M. London, and D.H. Ubelaker of the Department of Anthropology, National Museum of Natural History, Smithsonian Institution; I. Tattersall, K. Mowbray, and G. Sawyer of the Department of Anthropology, American Museum of Natural History (New York, NY); J. Spechit, P. Gordon, L. Bonshek, and N. Goodsell of the Department of Anthropology, Australian Museum (Sydney, Australia); J. Stone and D. Donlon of the Department of Anatomy and Histology, University of Sydney (Sydney, Australia); D. Henley of the New South Wales Aboriginal Land Council (Sydney, Australia); M. Chow, a dentist in Sydney; M. Hanihara of the School of Languages, Macquarie University (Sydney, Australia); C. Pardoe and G.L. Pretty of the Department of Anthropology, South Australian Museum (Adelaide, Australia); Y. H. Sinoto of the Department of Anthropology, B.P. Bishop Museum (Honolulu, HI); the late V.P. Alekseev of the Institute of Archaeology (Moscow, Russia); T.I. Alekseeva of the Moscow State University (Moscow, Russia); I.I. Gokhman and A.G. Kozintsev of the Museum of Anthropology and Ethnography (St. Petersburg, Russia); A.P. Derevyanko and T.A. Chikisheva of the Institute of Ethnography and Archaeology (Novosibirsk, Russia); G.I. Medbedev of Irkutsk State University (Irkutsk, Russia); T. Akazawa of the International Research Center for Japanese Studies; Hidemi Ishida of the Department of Zoology, Faculty of Science, Kyoto University (Kyoto, Japan); K. Katayama of the Primate Institution, Kyoto University (Inuyama, Japan); and G. Murakami of the Department of Anatomy, Sapporo Medical University (Sapporo, Japan). This study was supported in part by Grants-in-Aid for Scientific Research (10115204, 09839003, 1440521, and 14540659) from the Ministry of Education, Science and Culture of Japan; a Japan Fellowship for Research in the former Soviet Union (H.I.) and United Kingdom (T.H.) from the Japan Society for the Promotion of Science; and the Smithsonian Institution Fellowship Program,
Smithsonian Opportunities for Research and Study (Senior Fellowship in 2001-2002 to T.H.).

\section{LITERATURE CITED}

Balakrishnan V, Sanghvi LD. 1968. Distance between populations on the basis of attributed data. Biometrics 24:859-865.

Beals KL. 1972. Head form and climatic stress. Am J Phys Anthropol 37:85-92.

Berry AC, Berry RJ. 1967. Epigenetic variation in the human cranium. J Anat 101:361-379.

Brace CL, Nelson AR, Seguchi N, Oe H, Sering L, Pan Q, Li Y, Tumen D. 2001. Old World sources of the first New World human inhabitants: a comparative craniofacial view. Proc Nat Acad Sci USA 98:10017-10022.

Cann RL, Stoneking M, Wilson AC. 1987. Mitochondrial DNA and human evolution. Nature 325:31-36.

Cavalli-Sforza LL, Piazza A, Menozzi P, Mountain J. 1988. Reconstruction of human evolution: bringing together genetic, archaeological, and linguistic data. Proc Natl Acad Sci USA 85:6002-6006

Cavalli-Sforza LL, Menozzi P, Piazza A. 1994. The history and geography of human genes. Princeton: Princeton University Press.

Corruccini RS. 1974. An examination of the meaning of cranial discrete traits for human skeletal biological studies. Am J Phys Anthropol 40:425-446.

De Villiers H. 1968. The skull of the South African Negro. Johannesburg: Witwatersrand University Press.

Dodo Y. 1972. Aural exostosis in the human skeletal remains excavated in Hokkaido. J Anthropol Soc Nippon 80:11-22.

Dodo Y. 1974. Nonmetrical cranial traits in the Hokkaido Ainu and the northern Japanese of recent times. J Anthropol Soc Nippon 82:31-51.

Dodo Y. 1986a. Observations on the bony bridging of the jugular foramen in man. J Anat 144:153-165.

Dodo Y. 1986b. Population study of the jugular foramen bridging of the human cranium. Am J Phys Anthropol 69:15-19.

Dodo Y. 1987. Supraorbital foramen and hypoglossal canal bridging: the two most suggestive nonmetric cranial traits in discriminating major racial groupings of man. J Anthropol Soc Nippon 95:9-35.

Dodo Y, Ishida H, Saitou N. 1992. Population history of Japan: a cranial nonmetric approach. In: Akazawa T, Aoki K, Kimura T, editors. The evolution and dispersal of modern humans in Asia. Tokyo: Hokusen-sha. p 479-492.

Dodo Y, Doi N, Kondo O. 1998. Ainu and Ryukyuan cranial nonmetric variation: evidence which disputes the Ainu-Ryukyu common origin theory. Anthropol Sci 106:99-120.

Edwards AWF, Cavalli-Sforza LL. 1972. Affinity as revealed by differences in gene frequency. In: Weiner JS, Huizinga J, editors. The assessment of population affinities in man. Oxford: Clarendon Press. p 37-47.

Gershenson A, Nathan H, Luchansky E. 1986. Mental foramen and mental nerve: changes with age. Acta Anat (Basel) 126:2128.

Guglielmino-Matessi CR, Gluckman P, Cavalli-Sforza LL. 1979. Climate and the evolution of skull metrics in man. Am J Phys Anthropol 50:549-564.

Hanihara T, Ishida H. 2001a. Os incae: variation in frequency in major human populations. J Anat 197:137-152.

Hanihara T, Ishida H. 2001b. Frequency variations of discrete cranial traits in major human populations: I. Supernumerary ossicle variations. J Anat 198:689-706.

Hanihara T, Ishida H. 2001c. Frequency variations of discrete cranial traits in major human populations: II. Hypostotic variations. J Anat 198:707-725.

Hanihara T, Ishida H. 2001d. Frequency variations of discrete cranial traits in major human populations: III. Hyperostotic variations. J Anat 199:251-272.

Hanihara T, Ishida H. 2001e. Frequency variations of discrete cranial traits in major human populations: IV. Vessel and nerve related variations. J Anat 199:273-287. 
Hanihara T, Ishida H, Dodo Y. 1998a. Os zygomaticum bipartitum: frequency distribution in major human populations. $\mathrm{J}$ Anat 192:539-555.

Hanihara T, Ishida H, Dodo Y. 1998b. Place of the Hokkaido Ainu (northern Japan) among circumpolar and other peoples of the world: a comparison of the frequency variations of discrete cranial traits. Int J Circumpolar Health 57:257-275.

Hauser G, De Stefano GF. 1989. Epigenetic variants of the human skull. Stuttgart: Schweizerbart.

Hertzog KP. 1968. Associations between discontinuous cranial traits. Am J Phys Anthropol 29:397-404.

Howells WW. 1973a. Cranial variation in man: a study by multivariate analysis of patterns of difference among recent human populations. Papers of the Peabody Museum no. 67. Cambridge, MA: Peabody Museum, Harvard University. p 1-259.

Howells WW. 1973b. Measures of population distance. In: Crawford MH, Workman PL, editors. Methods and theories of anthropological genetics. Albuquerque: University of New Mexico Press. p 159-176.

Howells WW. 1989. Skull shapes and the map: craniometric analyses in the dispersion of modern Homo. Papers of the Peabody Museum no. 79. Cambridge, MA: Peabody Museum, Harvard University. p 1-189.

Howells WW. 1995. Who's who in skulls: ethnic identification of crania from measurements. Papers of the Peabody Museum no. 82. Cambridge, MA: Peabody Museum, Harvard University. $\mathrm{p}$ $1-108$.

Irish JD. 1997. Characteristic high- and low-frequency dental traits in Sub-Saharan African populations. Am J Phys Anthropol 102:455-467.

Irish JD. 1998. Ancestral dental traits in recent Sub-Saharan Africans and the origins of modern humans. J Hum Evol 34: 81-98.

Jidoi K, Nara T, Dodo Y. 2000. Bony bridging of the mylohyoid groove of the human mandible. Anthropol Sci 108:345-370.

Kennedy GE. 1986. The relationship between auditory exostosis and cold water: a latitudinal analysis. Am J Phys Anthropol 71:401-415.

Konigsberg LW. 1990. Analysis of prehistoric biological variation under a model of isolation by geographic and temporal distance. Hum Biol 62:49-70.

Lahr MM. 1994. The multiregional model of modern human origins: a reassessment of its morphological basis. J Hum Evol 26:23-56.

Lahr MM. 1995. Patterns of modern human diversification: implications for Amerindian origins. Yrbk Phys Anthropol 38: 163-198.

Lahr MM. 1996. The evolution of modern human diversity: a study of cranial variation. Cambridge: Cambridge University Press.

Lahr MM, Wright RVS. 1996. The question of robusticity and the relationship between cranial size and shape in Homo sapiens. J Hum Evol 31:157-191.

Manzi G, Vienna A, Hauser G. 1996. Developmental stress and cranial hypostosis by epigenetic trait occurrence and distribution: an exploratory study on the Italian Neanderthals. J Hum Evol 30:511-527.

Manzi G, Gracia A, Arsuaga J-L. 2000. Cranial discrete traits in the Middle Pleistocene humans from Sima de los Huesos (Sierra de Atapuerca, Spain): does hypostosis represent any increase in "ontogenetic stress" along the Neanderthal lineage? J Hum Evol 38:425-446.

Murphy T. 1957. The chin region of the Australian Aboriginal mandible. Am J Phys Anthropol 15:517-535.

Nei M, Roychoudhury AK. 1993. Evolutionary relationships of human populations on a global scale. Mol Biol Evol 10:927-943.

Omoto K. 1995. Genetic diversity and the origins of the "Mongoloids". In: Brenner S, Hanihara K, editors. The origin and past of modern humans as viewed from DNA. Singapore: World Scientific. p 92-109.

Omoto K, Saitou N. 1997. Genetic origins of the Japanese: a partial support for the dual structure hypothesis. Am J Phys Anthropol 102:437-446.
Ossenberg NS. 1969. Discontinuous morphological variation in the human cranium. Ph.D. thesis. Toronto: University of Toronto.

Ossenberg NS. 1970. The influence of artificial cranial deformation on discontinuous morphological traits. Am J Phys Anthropol 33:357-372.

Ossenberg NS. 1986. Isolate conservatism and hybridization in the population history of Japan: the evidence of nonmetric cranial traits. In: Akazawa T, Aikens CM, editors. Prehistoric hunter-gatherers in Japan. Tokyo: University of Tokyo Press. $p$ 199-215.

Powell JF, Neves WA. 1999. Craniofacial morphology of the first Americans: pattern and process in the peopling of the New World. Yrbk Phys Anthropol 42:153-188.

Relethford JH. 1994. Craniometric variation among modern human populations. Am J Phys Anthropol 95:53-62.

Relethford JH. 1999. Models, predictions, and the fossil record of modern human origins. Evol Anthropol 8:7-10.

Relethford JH, Harpending HC. 1994. Craniometric variation, genetic theory, and modern human origins. Am J Phys Anthropol 95:249-270.

Relethford JH, Harpending HC. 1995. Ancient differences in population size can mimic a recent African origin of modern humans. Curr Anthropol 36:667-674.

Relethford JH, Jorde LB. 1999. Genetic evidence for larger African population size during recent human evolution. Am J Phys Anthropol 108:251-260.

Relethford JH, Lees FC. 1982. The use of quantitative traits in the study of human population structure. Yrbk Phys Anthropol 25:113-132.

Ruiz-Linares A, Mich E, Meyer D, Cavalli-Sforza LL. 1995. Analysis of classical and DNA markers for reconstructing human population history. In: Brenner S, Hanihara K, editors. The origin and past of modern humans as viewed from DNA. Singapore: World Scientific. p 123-148.

Saitou N, Nei M. 1987. The neighbor-joining method: a new method for constructing phylogenetic trees. Mol Biol Evol $4: 406-425$

Scott GR, Turner CG II. 1997. The anthropology of modern human teeth: dental morphology and its variation in recent human populations. Cambridge: Cambridge University Press.

Sjøvold T. 1973. The occurrence of minor nonmetrical variants in the skeleton and their quantitative treatment for population comparisons. Homo 24:204-233.

Standen VG, Arriaza BT, Santoro CM. 1997. External auditory exostosisi in prehistoric Chilean populations: a test of the cold water hypothesis. Am J Phys Anthropol 103:119-129.

Stoneking M. 1993. DNA and recent human evolution. Evol Anthropol 2:60-73.

Stringer CB, Andrews P. 1988. Genetic and fossil evidence for the origin of modern humans. Science 239:1263-1268.

Stringer CB, Humphrey LT, Compton T. 1997. Cladistic analysis of dental traits in recent humans using a fossil outgroup. $J$ Hum Evol 32:389-402.

Templeton AR. 2002. Out of Africa again and again. Nature 416:45-51.

Thorne AG, Wolpoff MH. 1981. Regional continuity in Australasian Pleistocene hominid evolution. Am J Phys Anthropol 55: $337-349$.

Turner CG II. 1987. Late Pleistocene and Holocene population history of East Asia based on dental variation. Am J Phys Anthropol 73:305-321.

Turner CG II. 1990. Major features of sundadonty and sinodonty, including suggestions about East Asian microevolution, population history, and late Pleistocene relationships with Australian Aboriginals. Am J Phys Anthropol 82:295-317.

Turner CG II. 1992. Microevolution of East Asian and European populations: a dental perspective. In: Akazawa T, Aoki K, Kimura T, editors. The evolution and dispersal of modern humans in Asia. Tokyo: Hokusen-sha. p 415-438.

Turner CG II, Nichol CR, Scott GR. 1991. Scoring procedures for key morphological traits of the permanent dentition: the Arizona State University dental anthropology system. In: Kelley 
MA, Larsen CS, editors. Advances in dental anthropology. New York: Wiley-Liss. p 13-31.

Tyrrell AJ, Chamberlain H. 1998. Non-metric trait evidence for modern human affinities and the distinctiveness of Neanderthals. J Hum Evol 34:549-554.

Vigilant L, Stoneking M, Harpending H, Hawkes K, Wilson AC. 1991. African populations and the evolution of human mitochondrial DNA. Science 253:1503-1507.

Wolpoff MH. 1989. Multiregional evolution: the fossil alternative to Eden. In: Mellars P, Stringer CB, editors. The human revolution: behavioural and biological perspectives on the origins of modern humans. Edinburgh: Edinburgh University Press. p 62-108.

Wolpoff MH. 1992. Theories of modern human origins. In: Bräuer G, Smith FH, editors. Continuity or replacement: controversies in Homo sapiens evolution. Rotterdam: A.A. Balkema. p 25-63.

Wolpoff MH, Wu X, Thorne AG. 1984. Modern Homo sapiens origins: a general theory of hominid evolution involving the evidence from East Asia. In: Smith FH, Spencer F, editors. The origin of modern humans. New York: Alan R. Liss. p 411483. 